University of Nebraska - Lincoln

DigitalCommons@University of Nebraska - Lincoln

$5-1961$

\title{
Chromatographic Study of Ninhydrin-positive Substances in Etiolated Shoots from Control and Irradiated Maize Seeds
}

Francis A. Haskins

University of Nebraska-Lincoln, fhaskins@neb.rr.com

Follow this and additional works at: https://digitalcommons.unl.edu/agronomyfacpub

Part of the Plant Sciences Commons

Haskins, Francis A., "Chromatographic Study of Ninhydrin-positive Substances in Etiolated Shoots from Control and Irradiated Maize Seeds" (1961). Agronomy \& Horticulture -- Faculty Publications. 254.

https://digitalcommons.unl.edu/agronomyfacpub/254

This Article is brought to you for free and open access by the Agronomy and Horticulture Department at DigitalCommons@University of Nebraska - Lincoln. It has been accepted for inclusion in Agronomy \& Horticulture -Faculty Publications by an authorized administrator of DigitalCommons@University of Nebraska - Lincoln. 


\title{
Chromatographic Study of Ninhydrin-positive Substances in Etiolated Shoots from Control and Irradiated Maize Seeds ${ }^{1}$
}

\author{
F. A. Haskins
}

$\mathrm{T}$ REATMENT of dormant seeds of a wide variety of plants with $\mathrm{X}$ rays or thermal neutrons results in pronounced effects on stature, survival, and various other attributes in seedlings grown from the treated seeds $(1,2$, 3. 4, 5, 6). It seems highly probable that some of these effects involve alterations in the protein metabolism of the seedling, and these alterations might be expected to lead to changes in levels of such ninhydrin-positive substances as amino acids and peptides. This paper is concerned with a preliminary study in which filter paper chromatography was used to investigate possible differences in ninhydrin-positive substances in etiolated maize shoots grown from control and irradiated seeds.

\section{MATERIALS AND METHODS}

Seeds of the single-cross maize hybrid, W/f $9 \times \mathrm{Hy}$, were used in these studies. X-ray and thermal neutron treatments were administered at the Brookhaven National Laboratory under the supervision of Seymour Shapiro, whose cooperation is gratefully acknowledged. Irradiation procedures were similar to those which have been described elsewhere (3).

For the production of etiolated shoots. seeds were first treated with $1 \%$ sodium hypochlorite and were then allowed to germinate in water-saturated vermiculite in the dark at 2.4 C. A germination period of 6 days was used for all material. Following the germination period, etiolated shoots were separated from the temainder of the seedling at the scutellar node, and their lengths and weights were measured. Some of the shoots were dissected into the three major portions - first internode, coleoptile, and un expanded foliage leaves and shoot apex within the colcoptile (for convenience, the last portion will be referred to as "leaves") Preparations of entire shoots and of the three shoot portions were made by macerating the tissues in small test tubes, using a glass rod. The resulting juices wete chromatographed without dilution.

The following procedure was used in the chromatographic analysis of the tissue juices: 2-lambda portions of the juices were spotted on $23 \times 28 \mathrm{~cm}$. sheets of Whatman No. 1 filter paper. The solvent, consisting of 16 volumes of n-propyl alcohol, 4 volumes of water, and 1 volume of pyridine. Was allowed to ascend the sheets a total of three times. Sheets were air-dried between ascents, and heights of all ascents were similar. After the third ascent of the solvent. chromatograms were sprayed with a solution consisting of $0.25 \mathrm{~g}$. of ninhydrin in $100 \mathrm{~m} \mathrm{ml}$. of acetone. The sprayed sheets were air-dried for $1 \mathrm{~min}$. and were then heated 9 min. in an oven at approximately $90^{\circ}$ C.. after which they were treated in an Arnold steamer for 9 min. The steam treatment helped to intensify color of the ninhydrin-positive spots. Following

' Research was conducted under Contract No. AT( $11-1)-393$. U. S. Atomic Energy Commission. Published with the approval of the Director as paper No. 1063, Journal Series. Nebraska Agricultural Experiment Station. Received Sept. 15, 1960.

"Professor of Agronomy, Lniversity of Nebraska. Grateful acknowledgment is made to the following persons for their contributions to this study: to Anthony Esquivel, for his assistance in the laboratory; to C. O. Gardner and the staff of the Statistics Laboratory, Nebraska Agricultural Experiment Station, for assistance in statistical analysis of the data: and to Wirren W. Sahs. Foundation Seed Division. University of Nebraskal. for supplying the Wfo $\times$ Hy maize steds. 
Table 1-Lengths and fresh weights of 6-day etiolated maize shoots used in chromatographic work. The total number of seeds planted for each treatment was 36 .

\begin{tabular}{|c|c|c|c|}
\hline Treatmetat & No, ul shoots & Lunkth, mm. & Fresh weiglti, w \\
\hline & & $m e: t n+S E$ & metan! $\triangle E$ \\
\hline Control & :34 & $125: 8.1$ & $0.50+0.030$ \\
\hline $\begin{array}{l}20,000 \times X \text { rity } \\
40,000 \times \text { X ray } \\
40,000 \text { r X ray }\end{array}$ & $\begin{array}{l}35 \\
36 \\
36\end{array}$ & $\begin{array}{r}107+6.2 \\
53+2.3 \\
45+1.4\end{array}$ & $\begin{array}{l}0.42+0.025 \\
0.23+0.010 \\
0.16+0.004\end{array}$ \\
\hline 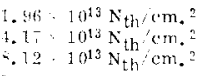 & $\begin{array}{l}36 \\
36 \\
36\end{array}$ & $\begin{array}{r}112+3.3 \\
2.5+2.6 \\
54 \pm 1.6\end{array}$ & $\begin{array}{l}0.45+0.016 \\
0.34+0.015 \\
0.20+0.008\end{array}$ \\
\hline
\end{tabular}

ninhydrin treatmont, chromatograms were cut into strips which could be accommodated in the Photovolt model 525 densitoneter. equipped with scanning stage for manual plotting of density value at $1 \mathrm{~mm}$. intervals on the strips. Filter No. 545 was used in the Jensitometer, and a round aperture $2 \mathrm{~mm}$. in diameter was $\mathrm{em}$ ployed. Measurements were confined to a vertical section through the approximate center of the chromatographic pattern on each strip.

To obtain an indication of relative quantities of ninbydrinpositive materials in the tissue juices, vertical lines were drawn separating the peaks on the densitometer graphs, and the sections were cut out and weighed to the nearest $0.1 \mathrm{mg}$. Measurements necessary for calculation of $\mathrm{Rf}$ values of the sections also were recorded.

Three series of determinations were completed, each series in rolving preparations of control material and material treated with $20,000,40,000$, or $80,000 \mathrm{r}$ of $\mathrm{X}$ rays or $1.96 \times 10^{\mathrm{T3}}, 4.17 \times 10^{13}$, or $8.12 \times 10^{13}$ thermal neutrons $/ \mathrm{cm}^{2}$. In each series, five preparations from each treatment were chromatographed: 2 entire-shoot preparations, and 1 preparation of first internodes. I of coleoptiles. and 1 of leaves. The entire-shoot preparations each consisted of the constituents of a single shoot, while in the preparations of internodes, coleoptiles, and leaves, corresponding parts of several dissected shoots were pooled. Duplicate determinations were made for each preparation. Thus, for the three series. 12 chromatographic strips of entire-shoot preparations and 6 strips each of first internode, coleoptile, and leaf preparations were analyzed for each treatment.

\section{RESULTS AND DISCUSSION}

The data on shoot length and weight (Table 1) clearly demonstrate the detrimental influence of the treatments on these attributes. Germination, on the other hand, was not reduced by the treatments, as indicated by the numbers of shoots harvested from a total of 36 seeds for each treatment.

Data on mean total weights of the cut-out densitometer graphs are shown in Table 2 . These weights may be taken as an indication of the total amounts of ninhydrin-positive substances in 2-lambda samples of the tissue juices. Also shown in the table are indications of significant differences among treatment means. It is apparent that significant increases in ninhydrin-positive substances were associated with the irradiation treatments, particularly with the X-ray treatments. Combined analysis of the data for entire and dissected shoots indicated that treatment differences, differences between entire shoots and the portions of dissected shoots, and differences among the three shoot portions were all significant at the $1 \%$ level of probability.

With very few exceptions, each densitometer graph consisted of 12 distinct sections. Rf values for the 12 sections were not appreciably influenced by treatment or by portion of the shoot, indicating that in terms of ninhydrin-positive substances all preparations were qualitatively similar to each other. Mean Rf values for the sections are listed in Table 3. Twenty-one known amino acids also were subjected to the chromatographic treatment used for the plant preparations. These amino acids are listed in Table 3 in line with the chromatographic sections to which they corresponded most closely in $\mathrm{Rf}$ value. All $\mathrm{Rf}$ values were calculated in the usual way by dividing the heights of the spots by the
Table 2-Quantity of ninhydrin-positive substances in control and irradiated material as indicated by mean total weights of densitometer graph sections.

\begin{tabular}{|c|c|c|c|c|}
\hline \multirow[t]{2}{*}{ Treatment } & \multicolumn{4}{|c|}{ Mean fruph wetghts (me) from preparations of } \\
\hline & $\begin{array}{l}\text { Entire } \\
\text { shoots }\end{array}$ & $\begin{array}{l}\text { First inter } \\
\text { nodes }\end{array}$ & $\begin{array}{l}\text { Coleop- } \\
\text { tiles }\end{array}$ & Leaves \\
\hline Control & inf. 0 & 200.8 & 162.2 & 200. \\
\hline $\begin{array}{l}20,000 \text { r X ray } \\
40,000 \text { r X ray } \\
80,000 \text { r X ray }\end{array}$ & $\begin{array}{l}212.4 \\
224.4 \\
2-1.4\end{array}$ & $\begin{array}{l}232.2 \\
260.1 \\
32 ! .8\end{array}$ & $\begin{array}{l}197.5 \\
244.2 \\
269.3\end{array}$ & $\begin{array}{l}223.2 \\
283.6 \\
282 .\end{array}$ \\
\hline $\begin{array}{l}1.96 \times 10^{13} \mathrm{~N}_{\mathrm{th}} / \mathrm{cm} .2 \\
4.17 \cdot 10^{13} \mathrm{~N}_{\mathrm{th}} / \mathrm{cm} . \\
8.12 \times 10^{13} \mathrm{~N} \text { th } / \mathrm{cm} .\end{array}$ & $\begin{array}{l}204.7 \\
201.5 \\
215.6 \\
\text { s of sig }\end{array}$ & $\begin{aligned} & 218.6 \\
& 245.3 \\
& 250.1 \\
& t \text { differences }\end{aligned}$ & $\begin{array}{l}195.2 \\
-336.2 \\
223.4 \\
e 56)\end{array}$ & $\begin{array}{l}218.1 \\
260 . \\
290.8\end{array}$ \\
\hline $\begin{array}{l}\text { Treatments } \\
\text { Control vs, irrad. } \\
\text { X ray vs. neutron } \\
\text { Within X ray } \\
\text { Within neutron }\end{array}$ & * & * & * & $\begin{array}{l}* * \\
* * \\
* \\
*\end{array}$ \\
\hline
\end{tabular}

Table 3-Mean Rf values of densitometer graph sections, and list of amino acids with comparable $R f$ values.

\begin{tabular}{|c|c|c|}
\hline $\begin{array}{l}\text { Section } \\
\text { number }\end{array}$ & $\begin{array}{c}\text { Mean } \\
R f\end{array}$ & A mino actils having comprarable Rf values \\
\hline 1 & $n$ & .... \\
\hline 2 & 0.4 & Crstine \\
\hline 3 & .09 & 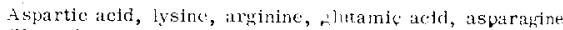 \\
\hline 4 & .13 & Gitumine \\
\hline$\overline{5}$ & .20 & Histidine, glyche, serine \\
\hline 6 & .27 & $\therefore$-aminobutyric acld \\
\hline i & .34 & Threontne, alanine \\
\hline 8 & $\therefore 3$ & Proline \\
\hline 9 & .52 & Tyroshe, tryptophan \\
\hline 10 & .61 & Vethionine, valine, pherylalanine \\
\hline 11 & .72 & Isoleucine, leuche \\
\hline 12 & נ19. & \\
\hline
\end{tabular}

height of the solvent front. Obviously, the values would not be expected to be directly comparable to $\mathrm{Rf}$ values obtained in systems using either more or fewer than three solvent ascents. The inclusion of this amino acid list is not intended to imply that the tissue constituents were positively identified. Such identification would involve considerably more elaborate chromatographic work than that which was done, including studies on hydrolysates of material from the various sections of the chromatograms, since it is probable that some of the sections represent peptides or other amino acid derivatives.

In order to investigate the possibility that the differences shown in Table 2 were confined primarily to a limited number of sections of the chromatograms, and otherwise to detect possible quantitative differences in the chromatographic patterns, calculations were made of the percentage contribution of each section of the densitometer graphs to the total weights of the graphs. The resulting data were subjected to analysis of variance, with separate analyses being done for each section and each type of preparation (entire shoot, first internode, etc.). It was found that significant treatment-associated differences in weight contribution existed for some of the sections, and that the patterns of difference were not the same for the four types of preparation. Only with respect to section 5, which ranked highest in weight contribution in all cases, was there a complete lack of statistically significant differences among the treatments. On the other hand, only in the case of section 9 were there significant differences among the treatments in all four types of preparation.

Mean percentage contributions of the 12 sections to total graph weight, without regard to type of preparation, are shown in Table 4. Analysis of these combined data disclosed that differences among treatments were statistically significant for sections 3,8 , and 9 . Weight contributions of sections 3 and 8 increased with dosage of irradiation 
Table 4-Combined data on chromatographic distribution of ninhydrin-positive substances in preparations of entire and dissected shoots from control and irradiated maize seeds.

\begin{tabular}{|c|c|c|c|c|c|c|c|c|c|c|c|c|}
\hline \multirow[t]{2}{*}{ Treatment } & \multicolumn{12}{|c|}{ Mean percentage contribution of section number } \\
\hline & 1 & 2 & $\because$ & 4 & 5 & 6 & $i$ & 8 & 9. & 10 & $1]$ & 12 \\
\hline Control & 5.6 & 5.8 & 4.6 & 4.2 & 21.1 & 10.2 & 12.3 & 11.0 & 10.3 & 4.5 & 6.6 & 3.7 \\
\hline $\begin{array}{l}20,000 \times \text { X ray } \\
40,000 \text { r X ray } \\
80,000 \text { × X ray }\end{array}$ & $\begin{array}{l}5.9 \\
5.6 \\
5.2\end{array}$ & $\begin{array}{l}5.5 \\
4.9 \\
4.2\end{array}$ & $\begin{array}{l}4.7 \\
5.8 \\
6.6\end{array}$ & $\begin{array}{l}4.7 \\
3.9 \\
3.8\end{array}$ & $\begin{array}{l}21.4 \\
20.1 \\
20.9\end{array}$ & $\begin{array}{r}8.3 \\
10.8 \\
11.4\end{array}$ & $\begin{array}{l}13.2 \\
12.3 \\
12.8\end{array}$ & $\begin{array}{l}11.9 \\
3.6 \\
14.9\end{array}$ & $\begin{array}{l}9.8 \\
9.1 \\
7.3\end{array}$ & $\begin{array}{l}4.6 \\
4.0 \\
3.6\end{array}$ & $\begin{array}{l}7.5 \\
7.5 \\
6.5\end{array}$ & $\begin{array}{l}2.5 \\
2.6 \\
2.2\end{array}$ \\
\hline $\begin{array}{l}1.96 \cdot 10^{13} \mathrm{~N}_{\mathrm{th}} / \mathrm{cm}_{-}: \\
4.17 \cdot 10^{13} \mathrm{~N}_{\mathrm{th}} / \mathrm{cm}^{2} \\
8.12 \cdot 10^{13} \mathrm{~N}_{\mathrm{th}} / \mathrm{cm}^{2}\end{array}$ & $\begin{array}{l}5.7 \\
5.6 \\
5.4\end{array}$ & $\begin{array}{l}5.5 \\
4.5 \\
5.2\end{array}$ & $\begin{array}{l}4.7 \\
5.2 \\
6.4\end{array}$ & $\begin{array}{l}3.6 \\
3.7 \\
3.9\end{array}$ & $\begin{array}{l}20.8 \\
21.7 \\
22.6\end{array}$ & $\begin{array}{l}9.4 \\
9.3 \\
9.3\end{array}$ & $\begin{array}{l}13.4 \\
13.7 \\
13.1\end{array}$ & $\begin{array}{l}12.7 \\
13.3 \\
14.7\end{array}$ & $\begin{array}{l}10.4 \\
10.4 \\
8.7\end{array}$ & $\begin{array}{l}4.6 \\
3.8 \\
3.6\end{array}$ & $\begin{array}{l}5.6 \\
6.7 \\
5.7\end{array}$ & $\begin{array}{l}2.8 \\
2.6 \\
1.7\end{array}$ \\
\hline \multicolumn{13}{|c|}{ Indications of significant differences ( $F$ test): } \\
\hline $\begin{array}{l}\text { Treatment } \\
\text { Type of preparation } \\
\text { Entire shoot vs, portions } \\
\text { Among portions }\end{array}$ & $\begin{array}{l}* * \\
* *\end{array}$ & $\begin{array}{l}* * \\
* *\end{array}$ & **** & $\begin{array}{l}* * \\
* * \\
* *\end{array}$ & $\begin{array}{l}* * \\
* * \\
* * \\
* *\end{array}$ & $\begin{array}{l}* * \\
* * \\
* *\end{array}$ & $* *$ & $\begin{array}{l}* * \\
* * \\
* * \\
* *\end{array}$ & $\begin{array}{l}* \\
* * \\
* * \\
* *\end{array}$ & * & ** & $*$ *.. \\
\hline $\begin{array}{l}\text { A mong portions } \\
\text { Treatment : type of preparation }\end{array}$ & $* *$ & $* *$ & 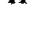 & $* *$ & ** & $* *$ & $\begin{array}{l}* * \\
* *\end{array}$ & $* *$ & $* *$ & * & $\begin{array}{l}* * \\
* *\end{array}$ & $* *$ \\
\hline
\end{tabular}

while that of section 9 decreased. Differences among shoot portions were significant (at the $1 \%$ level in most cases) for all sections. The interaction of treatment and type of preparation was also highly significant for most sections, emphasizing the difference in response of the various shoot portions to the treatments. On the basis of these findings it is reasonable to conclude that the three major portions of the etiolated shoot differ from each other with respect to quantities of the various ninhydrin-positive materials present; and that seed irradiation with $\mathrm{X}$ rays or thermal neutrons results in quantitative alterations in contents of ninhydrin-positive materials. Further work is needed to establish the precise nature of the compounds whose metabolism is altered and to elucidate the mechanism by which the alterations are brought about.

\section{SUMMARY}

Filter paper chromatography was used in a preliminary study of ninhydrin-positive substances in the juice of 6-day etiolated shoots and of the three major portions (first internode, coleoptile, and unexpanded foliage leaves) of such shoots from control and irradiated seeds of the maize hybrid Wf9 $\times \mathrm{Hy}$. Ninhydrin-positive substances were present at higher concentration in preparations of material grown from seeds treated with appropriate doses of $\mathrm{X}$ rays or thermal neutrons than in control material. Although all preparations appeared qualitatively similar with respect to variety of ninhydrin-positive substances, certain quantitative differences were associated with the irradiation treatments. Quantitative differences among the three shoot portions also were observed.

\section{LITERATURE CITED}

1. Beard, B. H., Haskins, F. A., and Gardner, C. O. Comparison of effects of $X$ rays and thermal neutrons on domant seeds of barley, maize, mustard, and safflower. Genetics $43: 728-736$ 1958.

2. CALDI:COTT, R. S. The effects of $X$ rays, 2-mev electrons, ther mal neutrons, and fast neutrons on dormant seeds of barley. Ann. N. Y. Acad. Sci. 59:514-535. 1955.

3. Haskins, F. A., and Chapman, H. W. Effects of irradiation maleic hydrazide, temperature, and age on enzyme activity in seedlings of corn (Zea ma)s L.). Physiol. Plant. 9:356-362 1956.

1. Schmidt, J. W., and Frolik, E. F. The effects of thermal neutron irradiation of maize and barley kernels. Nebraska Agr. Exp. Sta. Res. Bull. 167. 29 pages. 1951

5. SPENCER. J. L., and Cabanilias, E. The effects of $X$ rays and thermal neutrons on the development of trailing indigo lindigen fera endecapbylla) plants. Am. J. Bot. 43:289-296. 1956.

6. YAgYU, P., and Morkis, R. Cytogenetic effects of $X$ rays and thermal neutrons on dormant tomato seeds. Genetics 42:222238, 1957 . 